\title{
PEMBELAJARAN PEMECAHAN MASALAH MATEMATIS SISWA SEKOLAH DASAR DENGAN MODEL CREATIVE PROBLEM SOLVING (CPS)
}

\author{
Suprih Widodo ${ }^{1}$, Kartikasari ${ }^{2}$ \\ Program Studi Pendidikan Guru Sekolah Dasar \\ Universitas Pendidikan Indonesia Kampus Purwakarta \\ supri@upi.edu
}

\begin{abstract}
ABSTRAK
Kemampuan pemecahan masalah merupakan salah satu tujuan pembelajaran matematika, tetapi kemampuan pemecahan masalah matematis siswa tergolong rendah, berdasarkan hasil penelitian sebelumnya dan wawancara dengan guru sekolah dasar bahwa siswa belum terbiasa menyelesaikan soal pemecahan masalah (soal non rutin) sehingga siswa sulit memahami soal. Fakta tersebut merupakan latar belakang dari penelitian dengan tujuan untuk mengetahui apakah ada perbedaan kemampuan pemecahan masalah matematis siswa antara kelas yang menggunakan model pembelajaran Creative Problem Solving dengan kelas yang menggunakan metode konvensional. Metode penelitian yang digunakan adalah kuasi eksperimen dengan nonequivalent pretest-posttest control group design. Populasi dari penelitian yaitu kelas IV di salah satu SD Kecamatan Munjuljaya dengan sampel siswa kelas IVB dan kelas IVC. Teknik sampel yang digunakan yaitu purposive sampling. Instrumen yang digunakan adalah tes kemampuan pemecahan masalah yang diberikan sebelum dan sesudah perlakuan. Data dianalisis menggunakan statistik deskriptif dan statistik inferensial. Berdasarkan hasil penelitian dari skor $\mathrm{N}$-gain, rata-rata $\mathrm{N}$-gain kelas eksperimen tergolong sedang dan rata-rata kelas kontrol tergolong rendah dan dari hasil uji t dengan taraf kepercayaan 95\% menunjukkan tidak adanya perbedaan kemampuan pemecahan masalah matematis siswa antara kelas yang menggunakan model pembelajaran Creative Problem Solving dengan kelas yang menggunakan metode konvensional. Dibutuhkan pemahaman konsep matematika untuk dapat menyelesaikan kemampuan pemecahan masalah.
\end{abstract}

Kata kunci : Model Pembelajaran Creative Problem Solving (CPS), Kemampuan Pemecahan Masalah Matematis

\section{PENDAHULUAN}

Matematika adalah ilmu deduktif dan abstrak dengan menggunakan bahasa simbol yang sulit untuk dipahami oleh tahap perkembangan berpikir anak-anak usia SD yang belum formal dan relatif masih konkret. Menurut psikologi bangsa Swiss, Jean Piaget anak SD pada umumnya berada pada tahap berpikir operasional konkret yang belum dapat berpikir secara deduktif. Menurut Heruman (2008:2) mengemukakan bahwa "setiap konsep yang abstrak yang harus dipahami siswa perlu segera diberi penguatan, agar mengendap dan bertahan lama dalam memori siswa, sehingga akan 
melekat dalam pola pikir dan pola tindakannya". Matematika salah satu mata pelajaran penting yang memiliki tujuan umum berdasarkan NCTM yaitu: komunikasi matematis, penalaran matematis, pemecahan masalah matematis, koneksi matematis, representasi matematis. Winarni dan Harmini (2015:113) tujuan belajar matematika yang tertera dalam kurikulum mata pelajaran matematika sekolah pada semua jenjang pendidikan, yaitu: mengarah pada kemampuan siswa pada pemecahan masalah yang dihadapi dalam kehidupan sehari-hari.

Dalam pembelajaran di SD matematika menjadi mata pelajaran yang dianggap sulit bagi sebagian siswa. Selaras dengan pendapat Sriyanto, Russefendi dan Abdurrahman (dalam Husna dkk :176) mengatakan bahwa matematika merupakan momok yang menakutkan, mata pelajaran yang tidak disenangi dan mata pelajaran yang paling sulit dari mata pelajaran yang diajarkan. Beberapa penyebabnya yaitu pembelajaran yang dilakukan di sekolah tidak menyenangkan atau masih menggunakan metode ceramah dalam pembelajaran sehingga konsep matematika tidak tersampaikan, kemampuan siswa yang berbeda-beda, kesenangan/minat siswa terhadap matematika, tidak termotivasinya siswa untuk belajar matematika, kurang tersedianya alat peraga yang dapat membantu siswa memahami konsep matematika. Silver (dalam Turmudi, 2009 : 11) beragumentasi bahwa aktivitas siswa sehari-hari dalam pembelajaran matematika di kelas terdiri atas "menonton" gurunya, menyelesaikan soal-soal di papan tulis, kemudian bekerja sendiri dengan masalah-masalah (persoalan) yang disediakan dalam buku tradisional atau lembaran-lembaran kerja atau LKS.

Hasil survey Programme for International Student Assesment (PISA) oleh OECH mengenai kemampuan pemecahan masalah siswa pada domain pemecahan masalah matematis menunjukkan bahwa siswa Indonesia berada pada peringkat 64 dari 65 negara peserta (Putri, 2016). Hasil penelitian yang dilakukan Novianti, dkk. (2016: 402-403) mengemukakan bahwa rendahnya kemampuan pemecahan masalah dilihat dari hasil uji coba terbatas dengan jumlah 33 siswa diperoleh rata-rata 0,23. Berdasarkan hasil wawancara guru SD 1 Bae Kudus yang dilakukan oleh Ulya (2016: 92) yaitu sebagian besar siswa mengalami kesulitan dalam mengerjakan soal pemecahan masalah, karena soal tersebut memerlukan lebih dari satu langkah penyelesaian. Berdasarkan hasil wawancara penulis dengan guru SD kelas tinggi ditemukan permasalahan dalam pembelajaran matematika yaitu kurangnya kemampuan siswa dalam pemecahan masalah khususnya dalam penyelesaian masalah soal cerita. Siswa 
tidak terbiasa mengerjakan latihan tidak rutin, sehingga siswa kesulitan dalam menyelesaikan soal tersebut. Kurang memahami maksud dari soal cerita pada matematika menjadi faktor rendahnya kemampuan pemecahan masalah matematis siswa. Ketika siswa mengerjakan soal cerita guru membantu untuk memberikan pemahaman soal cerita tersebut, seperti memberitahu operasi perhitungannya, jika tidak diberi arahan seperti itu siswa akan kesulitan dan pada akhirnya siswa tidak bisa mengerjakan soal cerita dengan baik.

Berdasarkan fakta tersebut, diperlukan model pembelajaran dengan harapan kemampuan pemecahan masalah matematis siswa dapat tumbuh dan berkembang lebih baik. Upaya meningkatkan kemampuan pemecahan masalah matematis siswa melalui pembelajaran matematika, diharapkan dapat mengarahkan siswa untuk menyelesaikan pemecahan masalah matematika dalam kehidupan sehari-harinya. Menurut Muijs dan Reynolds (2008: 338) pengajaran matematika yang efektif melibatkan pengajaran untuk tujuan memahami, menggunakan problem-solving, dan lain-lain. Model pembelajaran Creative Problem Solving berpusat pada pemecahan masalah secara kreatif diharapkan membuat siswa mampu mengembangkan kemampuannya dalam menyelesaikan pemecahan masalah. Model pembelajaran Creative Problem Solving merupakan salah satu model pembelajaran berbasis masalah.

Model pembelajaran Creative Problem Solving dengan langkah-langkah menurut Pepkin (2000: 3) yaitu "The four phases will be: 1) clarification of the problemm (klarifikasi masalah), 2) brainstorming pengungkapan pendapat), 3) evaluation and selection (evaluasi dan pemilihan), 4) implementation (implementasi)".

Berdasarkan uraian tersebut, untuk mengetahui kemampuan pemecahan masalah matematis siswa dalam pelajaran matematika dilakukan sebuah penelitian dengan judul "Pengaruh Model Pembelajaran Creative Problem Solving Terhadap Kemampuan Pemecahan Masalah Matemtis Siswa Sekolah Dasar"

\section{METODE PENELITIAN}

Metode yang digunakan dalam penelitian ini adalah metode eksperimen dengan desain quasi experimental bentuk nonequivalebt pretest-posttest control grup design.

Populasi pada penelitian yaitu kelas IV disalah satu SD Kecamatan Munjuljaya. Teknik sampling yang digunakan adalah purposive sampling. Pemilihan kelas IVB dan IVC sebagai sampel berdasarkan pada pertimbangan bahwa tidak memiliki perbedaan 
yang berdasarkan atas uji t-test dengan mengukur rata-rata kemampuan awal matematika dasar. Pemilihan dua kelas yang akan menjadi kelas kontrol dan eksperimen dilakukan melalui pengundian. Sampel berjumlah 51 siswa dengan rincian kelas IVB 26 siswa sebagai kelas eksperimen dan kelas IVC 25 siswa sebagai kelas kontrol.

Instrumen yang digunakan untuk mengumpulkan data yaitu tes. Tes kemampuan pemecahan masalah matematis diberikan kepada kelas eksperimen dan kelas kontrol yang dilakukan dua kali, sebelum perlakuan (pretest) dan sesudah perlakuan (posttest). Tes berbentuk soal uraian (essay) sebanyak 6 soal. Instrumen yang digunakan sebagai soal pretest dan postest terlebih dahulu dijugment expert oleh dosen ahli dalam bidang pendidikan matematika sekolah dasar dan diuji coba untuk mengetahui tingkat kelayakan soal dengan diuji validitas, reliabilitas, daya pembeda, dan tingkat kesukarannya.

Indikator kemampuan pemecahan masalah yang diukur menurut Polya (1973) yaitu: memahami masalah, merancang rencana penyelesaian, melaksanakan rencana penyelesaian, dan melihat kembali langkah penyelesaian. Adapun pedoman penskoran kemampuan pemecahan masalah matematis siswa menurut Sumaryanta (2015:189) adalah sebagai berikut:

Tabel 1. Pedoman Penskoran Kemampuan Pemecahan Masalah Matematis

\begin{tabular}{cccc}
$\begin{array}{c}\text { Kriteria/ Indikator } \\
\text { Kemampuan } \\
\text { Pemecahan Masalah } \\
\text { Matematis }\end{array}$ & $\mathbf{0}$ & $\mathbf{1}$ & $\mathbf{2}$ \\
\hline $\begin{array}{c}\text { Memahami masalah } \\
\text { Kriteria/ Indikator } \\
\text { Kemampuan }\end{array}$ & $\begin{array}{c}\text { Tidak } \\
\text { memahami } \\
\text { masalah }\end{array}$ & $\begin{array}{c}\text { Kurang memahami } \\
\text { masalah }\end{array}$ & $\begin{array}{c}\text { Mampu } \\
\text { memahami } \\
\text { masalah }\end{array}$ \\
$\begin{array}{c}\text { Pemecahan Masalah } \\
\text { Matematis }\end{array}$ & $\mathbf{0}$ & $\mathbf{1}$ & $\mathbf{2}$ \\
\hline $\begin{array}{c}\text { Merumuskan } \\
\text { pemecahan masalah }\end{array}$ & $\begin{array}{c}\text { Tidak mampu } \\
\text { merumuskan } \\
\text { pemecahan }\end{array}$ & $\begin{array}{c}\text { Mampu } \\
\text { pemecahuskan masalah, } \\
\text { tetapi tidak tepat }\end{array}$ & $\begin{array}{c}\text { Merumpuskan } \\
\text { pemecahan } \\
\text { dengan tepat }\end{array}$ \\
\hline $\begin{array}{c}\text { Melaksanakan } \\
\text { pemecahan masalah }\end{array}$ & $\begin{array}{c}\text { Tidak mampu } \\
\text { melaksanakan } \\
\text { pemecahan } \\
\text { masalah }\end{array}$ & $\begin{array}{c}\text { Mampu } \\
\text { melaksanakan } \\
\text { pemecahan masalah, } \\
\text { tetapi tidak tepat }\end{array}$ & $\begin{array}{c}\text { Mampu } \\
\text { melaksanakan } \\
\text { pemecahan } \\
\text { masalah }\end{array}$ \\
\hline $\begin{array}{c}\text { Membuat kesimpulan } \\
\text { (memeriksa kembali) }\end{array}$ & $\begin{array}{c}\text { Tidak mampu } \\
\text { membuat } \\
\text { kesimpulan }\end{array}$ & $\begin{array}{c}\text { Mampu membuat } \\
\text { keismpulan, tetapi } \\
\text { tidak tepat }\end{array}$ & $\begin{array}{c}\text { Mampu membuat } \\
\text { kesimpulan }\end{array}$ \\
\hline
\end{tabular}


Data hasil pretest dan posttest diolah dan dianalsis sesuai dengan rumusan masalah yang telah dibuat dengan menggunakan statistik deskriptif dan statistik inferensial. Statistik deskriptif digunakan untuk menganalisis data dengan cara mendeskripsikan atau menggambarkan data yang telah terkumpul. Statistik deskriptif berupa rata-rata, skor minumum, skor maksimum, simpangan baku dan varians sedangkan statistik inferensial digunakan untuk menganalisis data dengan membuat generalisasi pada data sampel agar hasilnya dapat diberlakukan pada populasi. Statistik Inferensial terbagi menjadi statistik parametrik dan non parameterik. Statistik parametrik digunakan untuk menguji normalitas dan homogenitas suatu data. Sedangkan statistik non paramterik digunakan jika salah satu data atau keduanya tidak normal maupun homogen. Hasil akhir analisis penelitian ini akan menjawab rumusan masalah dan hipotesis penelitian.

\section{HASIL DAN PEMBAHASAN}

\section{Deskripsi Data Hasil Penelitian}

Data pretest, posttest, N-gain dilakukan perhitungan dengan menggunakan statistik deskriptif, hal ini akan menjawab rumusan masalah yang pertama yaitu "bagaimana deskripsi hasil belajar antara kelas yang menggunakan model pembelajaran Creative Problem Solving (CPS) dan di kelas yang menggunakan metode konvensional?" untuk menjawab rumusan tersebut dilakukan perhitungan data skor pretest dan skor postest kemampuan pemecahan masalah matematis siswa di kelas eksperimen dan kelas kontrol serta peningkatan skor pretest posttest (N-gain).

Langkah awal yang dilakukan terhadap kedua kelas sampel yaitu dengan pemberian soal pretest yang bertujuan untuk mengetahui kemampuan awal pemecahan masalah matematis siswa setara atau tidak.

Tabel 2. Statistik Deskriptif Rekapitulasi Hasil Pretest

\begin{tabular}{ccccccc}
\hline Kelas & $\mathbf{N}$ & $\overline{\mathbf{X}}$ & $\begin{array}{c}\text { Skor } \\
\text { Min }\end{array}$ & $\begin{array}{c}\text { Skor } \\
\text { Maks }\end{array}$ & SD & Var \\
\hline Eks & 26 & 13,2 & 1 & 32 & 8,67 & 75,17 \\
\hline Kon & 25 & 12,6 & 2 & 29 & 7,00 & 49 \\
\hline
\end{tabular}


Hasil perhitungan tersebut diketahui rata-rata skor pretest kelas eksperimen 13,2 dan rata-rata kelas kontrol 12,6. Rata-rata tersebut menunjukkan kelas eskperimen lebih tinggi dibandingkan kelas kontrol dengan selisih 0,6.

Setelah dilakukan pretest kelas eksperimen diberi perlakukan dengan model pembelajaran Creative Problem Solving dan kelas kontrol dengan metode konvensional. Pembelajaran dilakukan sebanyak 3 kali pertemuan dengan alokasi waktu 3 jam pelajaran (3 x 35 menit) kemudian siswa melakukan posttest untuk mengetahui kemampuan pemecahan masalah matematis siswa setelah pemberian perlakuan. Tabel 3 di bawah ini merupakan hasil perhitungan statistik deskriptif posttest siswa kelas eksperimen dan kelas kontrol dengan skor maksimal 48.

\begin{tabular}{ccccccc}
\multicolumn{1}{l}{ Tabel 3. Statistik Deskriptif Rekapitulasi Hasil Posttest } \\
\hline Kelas & N & $\overline{\mathbf{X}}$ & $\begin{array}{c}\text { Skor } \\
\text { Min }\end{array}$ & $\begin{array}{c}\text { Skor } \\
\text { Maks }\end{array}$ & SD & Var \\
\hline Eks & 26 & 24,4 & 3 & 46 & 11,61 & 134,79 \\
\hline Kon & 25 & 23,3 & 11 & 43 & 8,28 & 68,56 \\
\hline
\end{tabular}

Berdasarkan hasil perhitungan di atas diketahui rata-rata eksperimen 24,4 dan rata-rata kelas kontrol 23,3. Rata-rata tersebut menunjukkan kelas eksperimen lebih tinggi dibandingkan kelas kontrol dengan selisih 1,1. Peningkatan skor pretest dan posttest dari kelas eksperimen dan kelas kontrol dapat dilihat pada gambar 1.

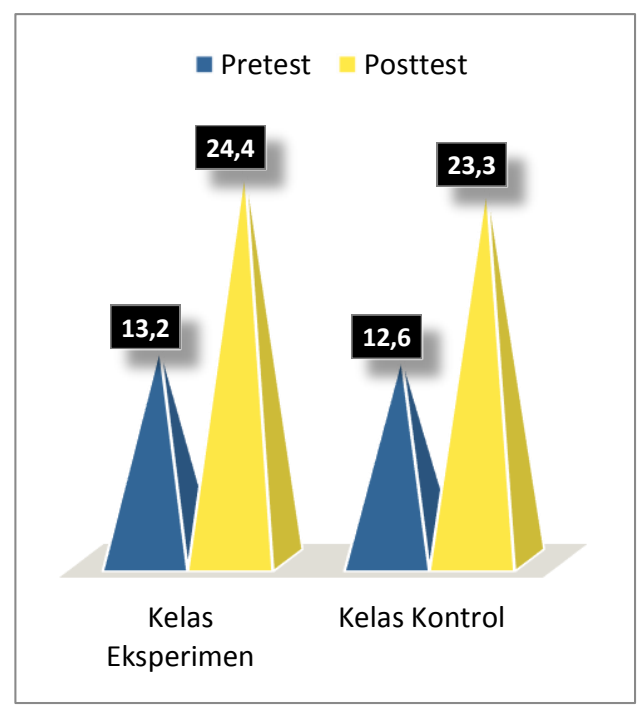

Gambar 1. Diagram Peningkatan Kemampuan Pemecahan Masalah Matematis Berdasarkan Skor Pretest dan Posttest 
Pada gambar di atas hanya menggambarkan perbedaan dan peningkatan yang dilihat dari nilai rata-rata. Selisih rata-rata posttest dan pretest kelas eksperimen yaitu 11,2 sedangkan selisih rata-rata posttest dan pretest kelas kontrol yaitu 10,7. Adanya peningkatan disebabkan karena siswa mulai memahami langkah-langkah mengerjakan soal pemecahan masalah matematis. Peningkatan kelas eksperimen lebih tinggi dibandingkan kelas kontrol karena pada pembelajaran kelas eksperimen siswa menggunakan langsung media pembelajaran untuk memecahan suatu permasalahan, siswa diminta untuk mengungkapkan ide/pendapatnya mengenai bagaimana kelompoknya mengerjakan permasalahan tersebut dengan media yang telah disiapkan, selain itu siswa dilatih belajar presentasi di depan kelas.

Tinggi rendahnya peningkatan skor pretest dan posttest dilihat berdasarkan kriteria nilai $\mathrm{N}$-gain nya, ada yang rendah, sedang dan tinggi. Pada gambar 2 dan 3 menjelaskan data peningkatan berdasarkan kriteria tersebut.

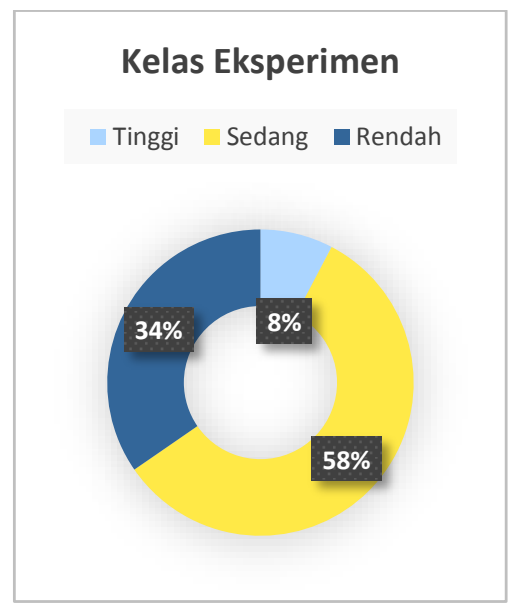

Gambar 2. Diagram Persentase N-Gain Kelas Eksperimen

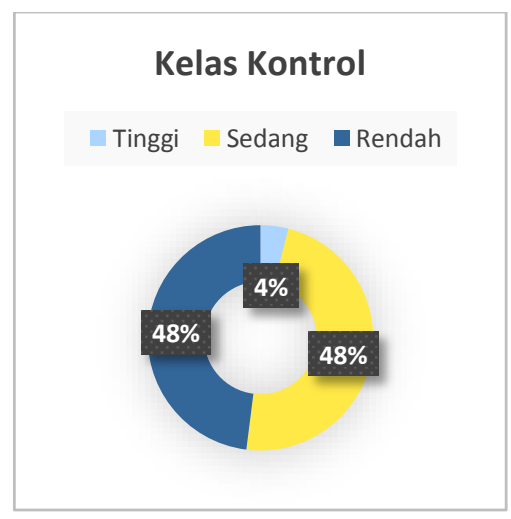

Gambar 3 . Diagram Persentase N-Gain Kelas Kontrol 
Berdasarkan gambar di atas pada siswa kelas eksperimen dan kelas kontrol siswa yang memiliki peningkatan kriteria tinggi sedikit, $8 \%$ siswa untuk kelas eksperimen dan 4\% siswa untuk kelas kontrol. Pada kelas eksperimen lebih dari setengah jumlah siswa banyak terdapat pada kriteria sedang dengan presentase 58\%. Sedangkan kelas kontrol antara kriteria sedang dan rendah sama yaitu $48 \%$.

Tabel 4. Statistik Deskriptif
\begin{tabular}{ccccccc} 
Kelas & N & $\overline{\mathbf{X}}$ & $\begin{array}{c}\text { Skor } \\
\text { Min }\end{array}$ & $\begin{array}{c}\text { Skor } \\
\text { Maks }\end{array}$ & SD & Var \\
\hline Eks & 26 & 0,38 & 0,02 & 0,92 & 0,239 & 0,057 \\
\hline Kon & 25 & 0,30 & 0,07 & 0,74 & 0,161 & 0,026 \\
\hline
\end{tabular}

Berdasarkan tabel di atas rata-rata $\mathrm{N}$-Gain kelas eksperimen sebesar 0,38 tergolong pada kriteria peningkatan sedang dan rata-rata $\mathrm{N}$-Gain kelas kontrol sebesar 0,3 tergolong pada kriteria peningkatan rendah. Selisih rata-rata skor N-Gain kelas eksperimen dan kelas kontrol yaitu 0,08. Perbedaan peningakatan antara skor pretest dan posttest kelas kontrol tidak jauh berbeda, namun kelas eksperimen peningkatannya lebih tinggi dibandingkan kelas kontrol.

\section{Perbedaan Kemampuan Pemecahan Masalah Matematis Siswa}

Perhitungan statistik inferensial akan menjawab rumusan masalah ke-2 yaitu, “apakah terdapat perbedaan yang signifikan pada kemampuan pemecahan masalah matematis siswa antara kelas yang menggunakan model pembelajaran Creative Problem Solving (CPS) dan di kelas yang menggunakan metode konvensional?" untuk menjawab rumusan masalah ke dua dilakukan uji beda rata-rata terhadap data skor pretest, posttest dan $\mathrm{N}$-gain kemampuan pemecahan masalah matematis siswa di kelas eksperimen dan kelas kontrol.

Data statistik deskripstif yang telah dijabarkan pada sebelumnya mungkin belum bisa menerangkan secara lengkap apakah kemampuan pemecahan masalah matematis siswa kelas eksperimen dan kelas kontrol berbeda atau sama pada hasil pretest, posttest dan N-gain oleh karena itu data dari hasil tersebut diuji dengan statistik inferensial. Statistik inferensial pretest dapat dilihat pada tabel 5. 
Tabel 5 Ringkasan Uji Statistik Skor Pretest Kemampuan Pemecahan Masalah Matematis Siswa di Kelas Eksperimen dan Kontrol

\begin{tabular}{|c|c|c|c|c|c|c|c|}
\hline Kelas & $\mathbf{n}$ & \multicolumn{2}{|c|}{ Uji Normalitas } & \multicolumn{2}{|c|}{ Uji Homogenitas } & \multicolumn{2}{|c|}{ Uji Parametrik (uji t) } \\
\hline Eks & 26 & $\begin{array}{l}\chi^{2} \text { hitung } \leq \chi_{\text {tabel }}^{2} \\
3,171 \leq 11,070\end{array}$ & Normal & $\begin{array}{l}F_{\text {hitung }} \leq \mathrm{F}_{\text {tabel }} \\
1,534 \leq 1,975\end{array}$ & Homogen & $\begin{array}{c}\mathrm{t}_{\text {hitung }} \leq \mathrm{t}_{\text {tabel }} \\
1,364 \leq 2,00958\end{array}$ & $\begin{array}{l}\text { Tidak ada } \\
\text { perbedaan }\end{array}$ \\
\hline Kon & 25 & $\begin{array}{l}\chi^{2} \text { hitung } \leq \chi^{2} \text { tabel } \\
2,380 \leq 11,070\end{array}$ & Normal & & & & \\
\hline
\end{tabular}

Keterangan : $\alpha=0,05$

Berdasarkan hasil uji beda rata-rata diketahui $t_{\text {hitung }} \leq t_{\text {tabel }}$ dengan 1,364 $\leq$ 2,00958 sehingga kelas eksperimen dan kelas kontrol berawal dari kemampuan pemecahan masalah matematis yang sama sebelum dilakukannya perlakuan, selanjutnya dilakukan uji beda rata-rata terhadap data posttest kemampuan pemecahan masalah matematis siswa di kelas eksperimen dan kelas kontrol. Statistik inferensial posttest dapat dilihat pada tabel 6 .

\section{Tabel 6. Ringkasan Uji Statistik Skor Posttest Kemampuan Pemecahan Masalah Matematis Siswa di Kelas Eksperimen dan Kontrol

\begin{tabular}{|c|c|c|c|c|c|}
\hline Kelas & $\mathbf{N}$ & \multicolumn{2}{|c|}{ Uji Normalitas } & $\begin{array}{l}\text { Uji non p } \\
\text { (uji Mann }\end{array}$ & $\begin{array}{l}\text { rametrik } \\
\text { Vhitney U) }\end{array}$ \\
\hline Eks & 26 & $\begin{array}{l}\chi^{2} \text { hitung } \leq \chi^{2} \text { tabel } \\
14,686 \leq 11,070\end{array}$ & $\begin{array}{c}\text { Tidak } \\
\text { normal }\end{array}$ & $\begin{array}{c}Z_{\text {hitung }} \leq Z_{\text {tabel }} \\
0,641<1,96\end{array}$ & $\begin{array}{l}\text { Tidak ada } \\
\text { perbedaan }\end{array}$ \\
\hline Kon & 25 & $\begin{array}{l}\chi^{2} \text { hitung } \leq \chi^{2} \text { tabel } \\
6,684 \leq 11,070\end{array}$ & Normal & & \\
\hline
\end{tabular}

Keterangan : $\alpha=0,05$

Berdasarkan hasil uji beda rata-rata posttest diketahui bahwa $Z_{\text {hitung }} \leq Z_{\text {tabel }}$ $(0,641<1,96)$ sehingga kelas eksperimen dan kelas kontrol tidak ada perbedaan. Analisis data tersebut tidak menggunakan uji homogenitas karena salah satu data tidak berdistribusi normal sehingga langsung pengujian non parametrik (uji Mann Whitney U). Pengerjaan soal posttest dilakukan sebanyak 3 kali. Pertemuan ke-1 kurang dari 15 siswa yang datang dari masing-masing kelas, selanjutnya diadakanlah posttest pertemuan ke-2, karena pada pertemuan ke-2 siswa belum mencapai 20 maka diadakan lagi pertemuan ke-3. Faktor yang mempengaruhi tidak adanya perbedaan antara kedua tersebut yaitu pada saat mengerjakan soal posttest siswa kelas eksperimen dilakukan di luar ruang belajar, kondisinya tidak kondusif dan proses pembelajaran di sekolah sedang tidak efektif. Hal ini membuat tingkat konsentrasi siswa kurang yang menyebabkan pengerjaan soal kurang teliti dan terlihat terburu-buru. 


\begin{tabular}{|c|c|c|c|c|c|c|c|}
\hline Kelas & $\mathbf{N}$ & \multicolumn{2}{|c|}{ Uji Normalitas } & \multicolumn{2}{|c|}{ Uji Homogenitas } & \multicolumn{2}{|c|}{ Uji Parametrik (uji t) } \\
\hline Eks & 26 & $\begin{array}{c}\mathrm{Sig} \geq 0,05 \\
0,200 \geq 0,05\end{array}$ & Normal & \multirow{5}{*}{$\begin{array}{c}\mathrm{Sig} \geq 0,05 \\
0,100 \geq 0,05\end{array}$} & \multirow{5}{*}{ Homogen } & \multirow[t]{2}{*}{$\begin{array}{c}t_{\text {hitung }} \leq \mathrm{t}_{\text {tabel }} \\
1,251 \leq 2,00958\end{array}$} & \multirow[t]{2}{*}{$\begin{array}{l}\text { Tidak ada } \\
\text { perbedaan }\end{array}$} \\
\hline \multirow[t]{4}{*}{ Kon } & 25 & \multirow{4}{*}{$\begin{array}{c}\mathrm{Sig} \geq 0,05 \\
0,200 \geq 0,05\end{array}$} & \multirow[t]{4}{*}{ Normal } & & & & \\
\hline & & & & & & Ket: $\alpha=0,05$ & \\
\hline & & & & & & $\begin{array}{r}\mathrm{t}_{\text {hitung }} \geq \mathrm{t}_{\text {tabel }} \\
1,251 \geq 1,242\end{array}$ & $\begin{array}{c}\text { Ada } \\
\text { perbedaan }\end{array}$ \\
\hline & & & & & & Ket: $\alpha=0,22$ & \\
\hline
\end{tabular}

Berdasarkan hasil uji beda rata-rata $\mathrm{N}$-gain bahwa $\mathrm{t}_{\text {hitung }} \leq \mathrm{t}_{\text {tabel }}(1,251 \leq 2,00958)$ sehingga tidak adanya perbedaan kelas eksperimen dan kelas kontrol pada taraf signifikansi 0,05 atau taraf kepercayaan 95\% Namun jika taraf signifikansi 0,22 atau taraf kepercayaan $78 \%$ antara kedua kelas tersebut terdapat perbedaan dengan $t_{\text {hitung }} \geq$ $\mathrm{t}_{\text {tabel }}(1,251 \geq 1,242)$. Analisis data tersebut menggunakan aplikasi SPSS dan manual.

Tidak adanya perbedaan antara kelas yang menggunakan model pembelajaran Creative Problem Solving (CPS) dengan metode konvensioal dapat diduga bahwa kedua kelas tersebut memiliki pemahaman konsep matematika yang rendah dalam penelitian ini pemahaman konsep tentang pecahan dan KPK perlu dipahami oleh siswa terlebih dahulu untuk memecahakan masalah sehingga dapat memahami masalah yang ada, jika siswa sudah memahami maka siswa dapat menentukan rencana penyelesaian dengan operasi hitung pecahan. Dilihat berdasarkan tes kemampuan awal matematika dasar, siswa belum memahami konsep dasar pecahan, mereka masih banyak yang tidak bisa melakukan operasi pecahan karena mereka tidak ingat cara menghitung KPK, selain itu kurangnya pemahaman konsep pecahan dilihat dari hasil pretest yang kecil.

Teori yang mendukung pernyataan di atas yaitu Halmos (dalam Wijaya, 2012: 58) mengungkapkan bahwa "kemampuan pemecahan masalah dipandang suatu keterampilan tingkat tinggi (high-level-skill)". Menurut Ulya (2016: 91) "kemampuan pemecahan masalah adalah kemampuan untuk menerapkan pengetahuan yang telah dimiliki sebelumnya kedalam situasi baru yang melibatkan proses berpikir tingkat tinggi”. Menurut Rofiqoh (2015: 21) "pemecahan masalah dalam matematika adalah suatu aktivitas untuk mencari penyelesaian dari masalah matematika yang dihadapi dengan menggunakan semua bekal pengetahuan matematika yang dimiliki”. Pendapat tersebut selaras dengan Adjie dan Maulana (2009: 4) bahwa "kemampuan untuk 
memecahkan masalah membutuhkan berbagai kemampuan yang ada pada diri seseorang sebagai hasil dari pengalaman belajar, yang mencakup pengetahuan, sikap dan psikomotor". Kemampuan pemecahan masalah adalah kemampuan untuk menerapkan pengetahuan yang telah dimiliki sebelumnya, diperlukannya pemahaman konsep matematika sebelum memecahkan suatu masalah matematika.

Setelah dilakukan pembelajaran selama 3 kali pertemuan, hasil posttestnya meningkat walaupun masih beberapa siswa yang bingung karena tidak semua anak ikut dalam pembelajaran yang dilakukan 3 kali pertemuan. Pembelajaran pecahan yang hanya dilakukan 3 kali sangat singkat untuk mengajarkan siswa mengenai pecahan yang pada dasarnya siswa belum memahami konsep pecahan. Sejalan dengan pernyataan di atas menurut Putri, H.E. (2011: 24) mengatakan bahwa "tingginya tingkat pemahaman dalam memaknai sebuah permasalahan akan berpengaruh postif terhadap peningkatan hasil belajar". Kemampuan pemecahan masalah sangat berhubungan dengan kemampuan representasi. Montague (dalam Fadillah, 2009) mengatakan bahwa "pemecahan masalah yang sukses tidak mungkin tanpa representasi masalah yang sesuai. Siswa yang mempunyai kesulitan dalam merepresentasikan masalah matematika akan memiliki kesulitan dalam melakukan pemecahan masalah". Menurut Kartini (2009) "kemampuan representasi matematis adalah kemampuan mengungkapkan ideide matematika (masalah, pernyataan, solusi, definisi, dan lain-lain) kedalam salah satu bentuk: (1) gambar, diagram grafik, atau tabel; (2) notasi matematik, numerik/simbol aljabar; dan (3) teks tertulis/kata-kata, sebagai interpretasi dari pikirannya”. Pernyataan di atas menunjukkan bahwa kemampuan pemecahan masalah melibatkan proses berpikir tingkat tinggi.

Dugaan ke-2 tidak ada nya perbedaan antara kedua kelas tersebut dapat dilihat pengelompokkan berdasarkan kriteria hasil $\mathrm{N}$-gain pada tabel 7 perbandingan peningkatan kemampuan pemecahan masalah matematis kelas eksperimen dan kontrol, dikelompokan berdasarkan peningkatan $\mathrm{N}$-gain nya yaitu kelompok tinggi, sedang dan rendah. Pada kelas eksperimen dan kelas kontrol hanya 1 dan 2 siswa yang terdapat pada kelompok tinggi, kelompok sedang kelas eksperimen 15 siswa dan kelas kontrol 12 siswa, kelompok rendah kelas eksperimen 9 siswa dan kelas kontrol 12 siswa. Berdasarkan pengelompokan tersebut dapat disimpulkan bahwa tidak adanya selisih yang berbeda jauh, selisihnya hanya berkisar 1-3 siswa disetiap kelompoknya. 92\% 
siswa kelas eksperimen dan $96 \%$ siswa kelas kontrol berada pada kelompok rendah dan sedang.

\section{KESIMPULAN}

Berdasarkan hasil penelitian melalui proses pengolahan data menggunakan statistik deskriptif dan statistik inferensial serta pembahasan hasil penelitian yang telah dilakukan mengenai pengaruh model pembelajaran Creative Problem Solving (CPS) terhadap kemampuan pemecahan masalah siswa sekolah dasar, menyimpulkan bahwa:

1. Deskripsi hasil belajar pada kelas eksperimen yang menggunakan model pembelajaran Creative Problem Solving lebih tinggi dibandingkan kelas yang menggunakan metode konvensional dilihat dari rata-rata pretest kelas eksperimen 13,2 dan kelas kontrol 12,6 , posttest kelas eksperimen 24,4 dan kelas kontrol 23,3 kemudian hasil $\mathrm{N}$-Gain kelas eksperimen 0,38 dengan kriteria sedang dan kelas kontrol 0,3 dengan kriteria rendah.

2. Tidak terdapat perbedaan yang signifikan terhadap kemampuan pemecahan masalah matematis siswa antara kelas eksperimen yang menggunakan model pembelajaran Creative Problem Solving dengan kelas kontrol yang menggunakan metode konvensional, dilihat dari hasil uji nonparametrik posttest dengan tingkat kepercayaan 95\%, $Z_{\text {hitung }}$ sebesar 0,641 $<Z_{\text {tabel }}(1,96)$. Berdasarkan parametrik analisis data $\mathrm{N}$-Gain dengan tingkat kepercayaan 95\%, $\mathrm{t}_{\text {hitung }}$ sebesar $1,251<\mathrm{t}_{\text {tabel }}$ $(2,00958)$. Namun ada perbedaan kemampuan pemecahan masalah matematis antara kedua kelas tersebut pada tingkat kepercayaan $78 \%$, $t_{\text {hitung }}$ sebesar 1,251 > $\mathrm{t}_{\text {tabel }}(1,242)$.

\section{REFERENSI}

Adjie, N. \& Maulana (2009). Pemecahan Masalah Matematis. Bandung. UPI Press.

Fadillah, S. (2009). Kemampuan Pemecahan Masalah Matematis dalam Pembelajaran Matematika, Prosiding Seminar Nasional Penelitian, Pendidikan dan Penerapan MIPA (hlm. 553-558). Yogyakarta: UNY.

Heruman. (2008). Model Pembelajaran Matematika di Sekolah Dasar.Bandung: Remaja Rosdakarya.

Husna, R., Saragih. S., \& Siman. (t.t). Peningkatan Kemampuan Pemecahan Masalah dan Komunikasi Matematika melalui Pendekatan Matematika Realistik pada Siswa SMP Kelas VIII Langsa. Jurnal Pendidikan Matematika PARADIKMA, 6(2):. 175-186. 
Kartini (2009). Peranan Representasi Dalam Pembelajaran Matematika, Prosiding Seminar Penelitian Matematika dan Pendidikan Matematika, (hlm. 361-371)

Muijs, D. \& Reynolds, D. (2008). Effective Teaching Teori dan Aplikasi. Yogyakarta: Pustaka Pelajar.

Novianti, E., Isrok'atun, \& Kurniadi, Y. (2016). Pendekatan Eksploratif untuk Meningkatkan Kemampuan Pemecahan Masalah Matematis dan Motivasi Belajar Siswa. Jurnal Pena Ilmiah, 1(1):. 401-410.

Pekpin, K.L.(2000). Creative Problem Solving in Math. [Online]. Diakses dari: http://www.uh.edu/honors/Programs-Minors/honors-and-the-schools/houstonteachers-institute/curriculum-units/pdfs/2000/articulating-the-creativeexperience/pepkin-00-creativity.pdf

Polya, G. (1973). How to Solve It: a New Aspect of Mathematics Method 2nd Edition. New Jearsey: Princeton University Press.

Putri, H. E. (2011). Pemecahan Masalah dalam Pembelajaran Matematika di SD. Jurnal Pendidikan ke-SD-an, 5(2):. 24-36.

Putri, I. A. (2016). Kemampuan Pemecahan Masalah Matematis melalui Pembelajaran dengan Model Designed Students Centered Instructionl (DCSI). Jurnal PGSD Kampus Cibiru, 4(4): 1-8.

Rofiqoh, Z. (2015). Analisis kemampuan pemecahan masalah matematika siswa kelas $x$ dalam pembelajaran discovery learning berdasarkan gaya belajar siswa. (Skripsi). Jurusan Matematika. Universitas Negeri Semarang. [Online]. Diakses dari lib.unnes.ac.id.

Sumaryanta. (2015). Pedoman Penskoran. Indonesian Digital Journal of Mathematics and Education. 2(3):. 181-190.

Turmudi. (2009). Taktik dan Strategi Pembelajaran Matematika Referensi untuk Guru Matematika Seri 4. Jakarta: PT Leuser Cita Pustaka.

Ulya, H. (2016). Profil Kemampuan Pemecahan Masalah Siswa Bermotivasi Belajar Tinggi Berdasarkan Ideal Problem Solving. Jurnal Konseling GUSJIGANG, 2(1):. 90-96.

Winarni, E. S \& Harmini (2015). Matematika untuk PGSD. Cetakan Keempat. Bandung: PT Remaja Rosdakarya.

Wijaya, A. (2012). Pendidikan Matematika Realistik Suatu Alternatif Pendekatan Pembelajaran Mateamatika. Yogyakarta: Graha Ilmu. 